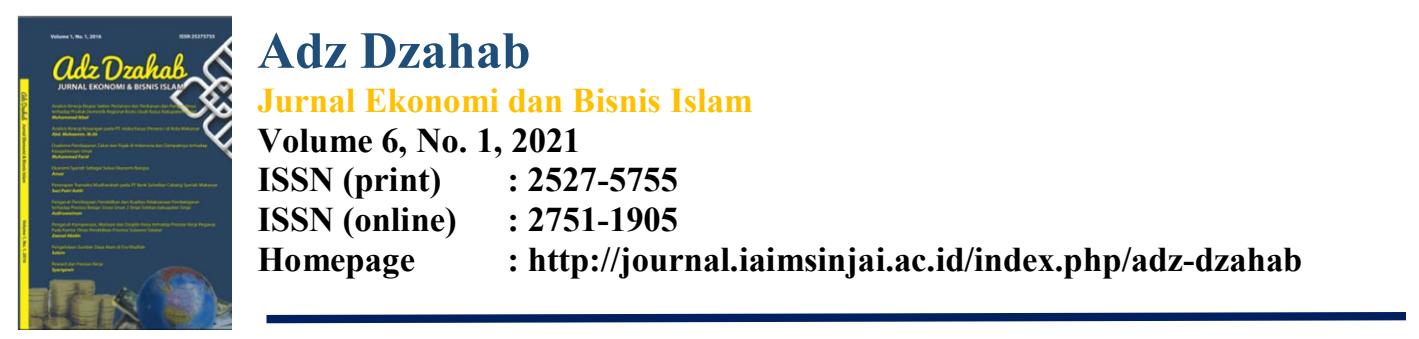

\title{
DETERMINAN FAKTOR YANG MEMENGARUHI PENDAPATAN ASLI DAERAH (PAD) DI KABUPATEN MAJENE
}

\author{
Haerana ${ }^{1}$ \\ ${ }^{1}$ Universitas Sulawesi Barat \\ Email/Tlp : andihaerana84@gmail.com/085243888892
}

\begin{abstract}
Abstrak
Tujuan penelitian determinan faktor yang memengaruhi pendapatan asli daerah di kabupaten Majeneini yaitu untuk menngetahui bagaimana determinan faktor yang memengaruhi pendapatan asli daerah (PAD) di kabupaten Majene. Jenis penelitian penelitian deskriptif kuantitatif, tekhnik analisis data dalam penelitian ini adalah statistk inferensial. Hasil penelitan ini menujukkan bahwa Secara parsial pertumbuhan penduduk berpengaruh tetapi tidak signifikan terhadap pendapatan asli daerah kabupaten Majene, produk domestik regional bruto berpengaruh dan signifikan terhadap pendapatan asli daerah kabupaten Majene, pajak daerah berpengaruh dan signifikan terhadap pendapatan asli daerah kabupaten Majene, retribusi daerah berpengaruh dan signifikan terhadap pendapatan asli daerah kabupaten majene, hasil pengelaloaan kekayaan daerah yang dipisahkan berpengaruh tetapi tidak signifikan terhadap pendapatan asli daerah kabupaten Majene, lain-lain pendapatan asli daerah yang sah berpengaruh dan signifikan terhadap pendapatan asli daerah kabupaten Majene. Secara simultan jumlah penduduk, produk domestik regional bruto, pajak daerah, retribusi daerah, hasil pengelolaan kekayaan daerah yang dipisahkan dan lain-lain pendapatan asli daerah berpengaruh dan signifikan terhadap pendapatan asli daerah di kabupaten Majene.
\end{abstract}

Kata kunci: Pendapatan Asli Daerah, Produk Domestik Bruto

\section{Pendahuluan}

Indonesia adalah Negara kesatuan yang berbentuk Republik dimana di dalamnya dikenal adanya daerah-daerah otonom sebagai konsekuensi dianutnya asas desentralisasi sesuai dengan ketentuan UU No 12 tahun 2008 maka ada 2 (dua) tingkatan daerah otonom yaitu daerah yang mengurus rumah tangganya sendiri, yang dibagi menjadi daerah tingkat I (Propinsi) dan daerah tingkat II (Kabupaten dan kota Madya). Dengan diberlakukannya Otonomi Daerah, Kabupaten dan Kota memiliki dengan Undang- Undang Nomor 33 Tahun 2004 tentang perimbangan keuangan antara pemerintah pusat dengan pemerintah daerah serta peraturan pemerintah pendukungnya

Adapun sumber-sumber pendapatan asli daerah menurut undang -undang Nomor 33 Tahun 2004 antara lain:

a. Pendapatan Asli Daerah (PAD) yang terdiri dari :

1. Hasil pajak daerah

2. Hasil retribusi daerah

3. Hasil pengelolaan kekayaan milik daerah yang dipisahkan

4. Lain- lain pendapatan asli daerah yang sah

b. Sumbangan dari pemerintah

c. Dan lain-lain pendapatan yang sah 


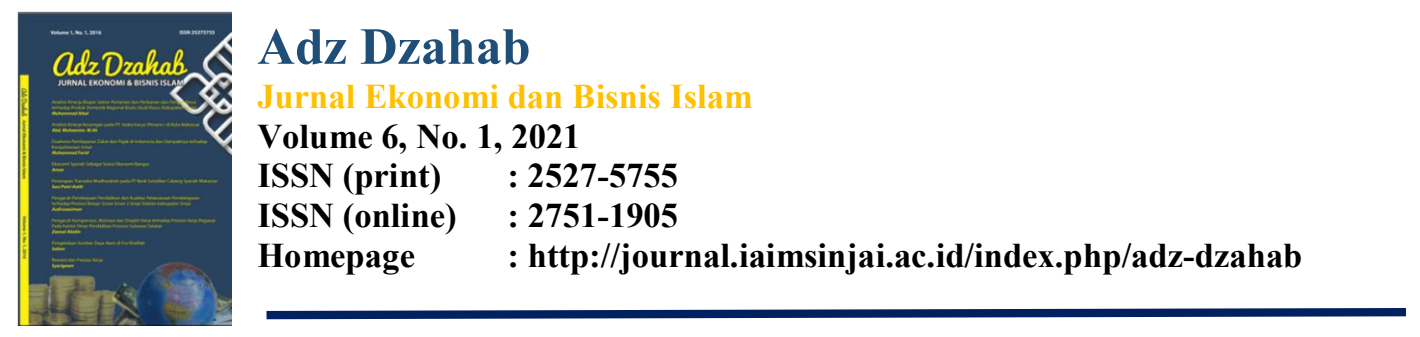

Pada prinsipnya semakin besar kontribusi PAD dalam Anggaran Pendapatan dan Belanja Daerah (APBD) maka semakin kecil tingkat ketergantungan daerah kepada pemerintah pusat, baik dalam bentuk block grand maupun specific grand. Sebaliknya semakin rendah kontribusi PAD dalam APBD maka semakin besar ketergantungan daerah pada pemerintah pusat, sehingga peran pemerintah pusat dalam mengalokasikan anggaran kedaerah dalam rangka pelaksanaan otonomi daerah cenderung dominan.

Pendapatan Asli daerah memiliki kaitan terhadap jumlah penduduk, artinya semakin banyak jumlah penduduk maka semakin banyak yang bekerja dan secara tidak langsung berpengaruh terhadap pendapatan asli daerah. faktor penduduk merupakan salah satu unsur penting dalam perencanaan dan pelaksanaan pembangunan. Pembangunan yang dilakukan pemerintah ditujukan untuk kemakmuran masyrakat yang berarti posisi penduduk dalam hal ini sebagai objek pembangunan tersebut salah satunya yang bersumber dari pendapatan asli daerah.

Berdasarkan data jumlah penduduk kabupaten Majene pada tahun 2007 sebesar 132.900 jiwa, dan jumlah penduduk dikabupaten Majene terus mengalami peningkatan sampai pada tahun 2016 menjadi sebesar 166.397. Dan tentunya jumlah tenaga kerja terus bertambah seiring dengan peningkatan jumlah penduduk. Dan sesuai dengan karakteristik wilayah komposisi penduduk yang bekerja didominasi pada lapangan usaha pertanian, perikanan dan kehutanan, namun setiap tahunnya terus menurun. Lapangan usaha yang mulai menarik perhatian adalah sektor jasa dan perdagangan dan sektor yang masih kurang diminati adalah sektor manufaktur.

Keadaan struktur ekonomi dan sosial suatu daerah menentukan besar kecilnya keinginan pemerintah untuk menetapkan pungutan-pungutan. Hal ini disebabkan karena struktur sosial dan ekonomi suatu masyarakat menentukan tinggi rendahnya tuntutan akan adanya pelayanan publik dalam kualitas dan kuantitas tertentu. Pada masyarakat agraris tuntutan akan ketersediaan fasilitas pelayanan publik dalam kualitas dan kuantitas tertentu akan lebih rendah daripada tuntutan yang ada dimasyarakat industri.

Indikator sederhana untuk melihat kondisi awal suatu daerah adalah dengan melihat kontribusi sektor pertanian dan industri pada Produk Domestik Regional Bruto (PDRB). Semakin tinggi kontribusi sektor industri pada PDRB suatu daerah maka semakin tinggi potensi penerimaan daerahnya. Sebaliknya semakin tinggi kontribusi sektor pertanian pada PDRB suatu daerah maka akan semakin rendah potensi penerimaan daerahnya.

Berdasarkan uraian diatas terkait dengan faktor-faktor yang mempengaruhi realisasi pendapatan asli daerah (PAD), maka penulis tertarik untuk meneliti PAD kabupaten majene dan menuangkankan hasilnya dalam karya ilmiah berjudul "Determinan faktor yang memengaruhi Pendapatan Asli Daerah (PAD) di Kabupaten Majene ".

Berdasarkan latar belakang yang telah penulis paparkan di atas, maka dapat dirumuskan permasalahan sebagai berikut:

a. Seberapa besar pengaruh jumlah penduduk, produk domestik regional bruto, (PDRB), pajak daerah, retribusi daerah, hasil pengelolaan kekayaan alam yang dipisahkan, dan lain-lain pendapatan asli daerah yang sah terhadap pendapatan asli daera secara parsial dikabupaten Majene tahun 2009-2016.

b. Seberapa besar pengaruh pengaruh jumlah penduduk, produk domestik regional bruto, (PDRB), pajak daerah, retribusi daerah, hasil pengelolaan kekayaan alam yang dipisahkan, dan lain-lain pendapatan asli daerah yang sah terhadap pendapatan asli daera secara simultan dikabupaten Majene 2009- 2016.

\section{Metode Penelitian}

Permasalahan, maka jenis penelitian ini adalah penelitian deskriptif kuantitatif dengan meneliti determinan faktor yang mempengaruhi pendapatan asli daerah 


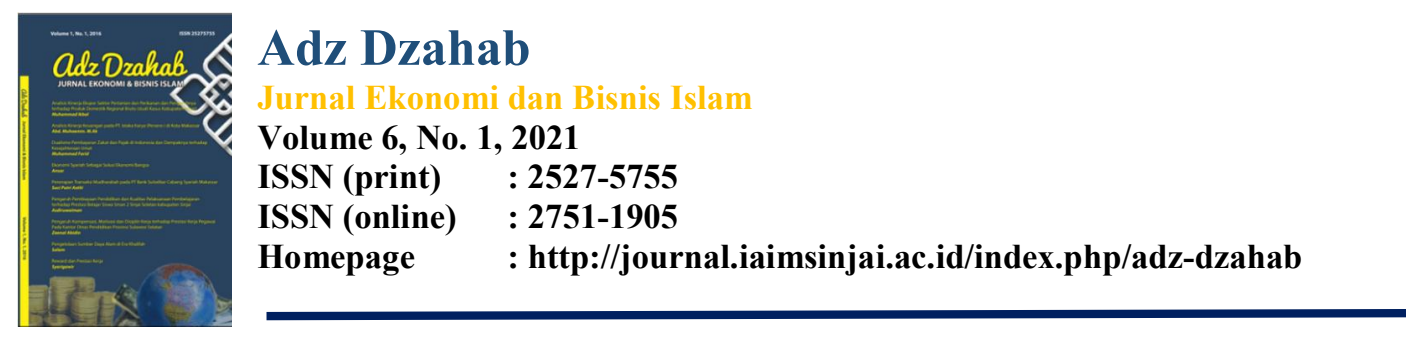

diKabupaten Majene. Adapun lokasi penelitian yaitu diwilayah kabupaten Majene propinsi Sulawesi Barat, pengambilan data diperoleh dari beberapa instansi terkait yaitu Dinas Pendapatan Daerah (DISPENDA) Kabupeten Majene, dan Badan Pusat Statistik (BPS) kabupaten Majene.

\subsection{Variabel Penelitian}

Variabel penelitian merupakan indikator penelitian penting yang menentukan keberasilan penelitian. Penelitian ini bertujuan untuk mengetahui determinan faktor yang mempengaruhi pendapatan asli daerah diKabupaten Majene. Olehnya itu, variabel dalam penelitian ini terdiri variabel bebas dan variabel terikat. Variabel bebas (independens variable) adalah adalah variabel yang mempengaruhi atau menjadi sebab timbulnya variabel X. Dalam penelitian ini variabel bebas yang dimaksud adalah Jumlah penduduk, PDRB, pajak daerah, retribusi daerah, hasil pengelolaan kekayaan alam kekayaan alam yang dipisahkan, dan lain-lain pendapatan asli daerah yang sah dikabupaten Majene sedangkan variabel terikat (independent variable) adalah variabel yang dipengaruhi atau merupakan variabel yang menjadi akibat dari

adanya variabel bebas yang biasanya disimbolkan dengan $\mathrm{Y}$.

\subsection{Desain Penelitian}

Desain penelitian merupakan suatu rancangan penelitian dalam rangka memperoleh data yang dibutuhkan berdasarkan variabel-variabel yang akan diteliti. Maka desain penelitian yang digunakan adalah pengumpulan data-data yang berhubungan dengan variabel yang diteliti dengan menggunakan teknik observasi, wawancara dan dokumentasi. Untuk lebih jelasnya, desain dalam penelitian ini digambarkan skema berikut

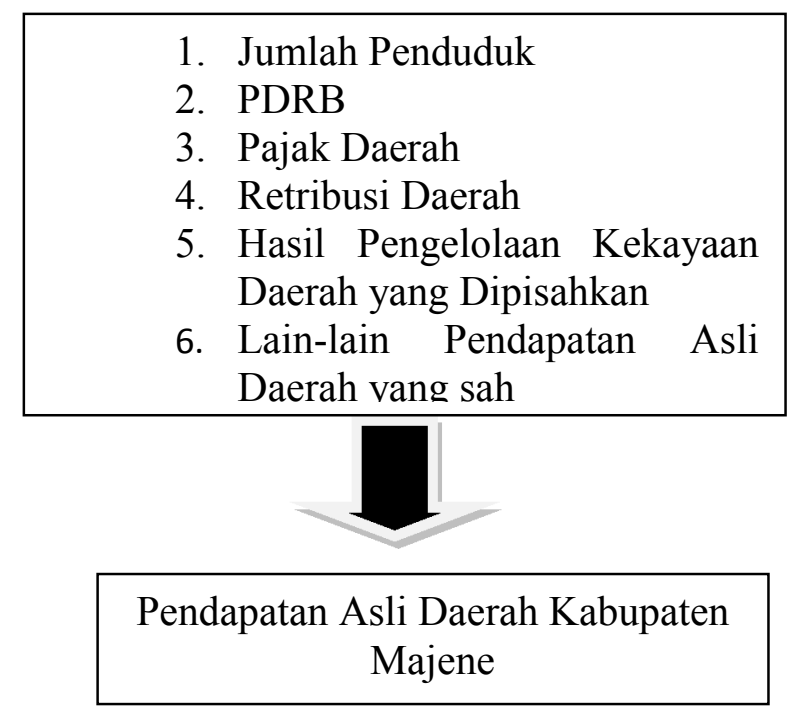

Gambar 3.1 Skema Desain Penelitian

\subsection{Definisi Operasional Variabel}

Defenisi operasional variabel merupakan batasan-batasan yang dipakai untuk menghindari interpretasi lain terhadap variabel yang diteliti. Adapun defenisi operasional variabel penelitian ini adalah sebagai berikut :

\section{a. Determinan}

Determinan adalah faktor yang menentukan Pendapatan Asli daerah kabupaten Majene tahun 2006-2015

b. Pendapatan Asli Daerah Kabupaten Majene 


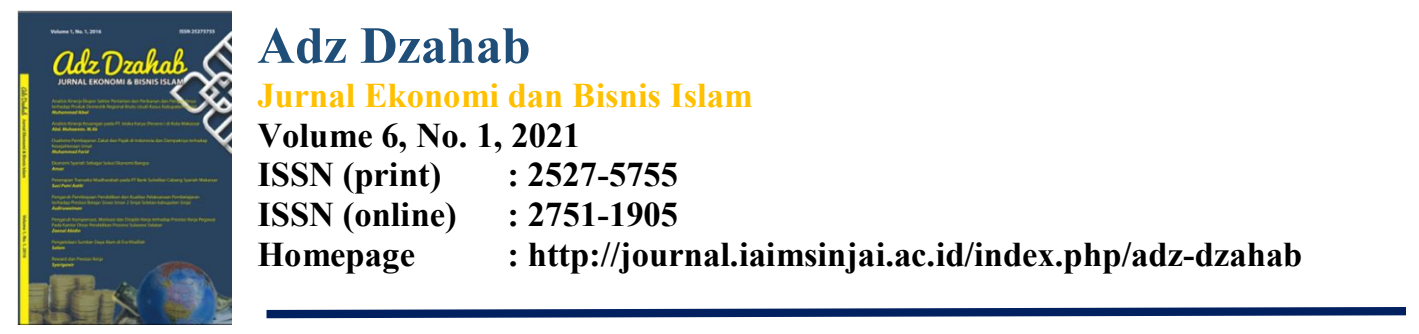

Pendapatan asli daerah adalah total pendapatan daerah kabupaten Majene dalam kurun waktu satu tahun selama 10 tahun dari tahun 2006 - 2015 yang diukur dengan menggunakan rupiah.

c. Jumlah penduduk

Jumlah Penduduk adalah jumlah manusia yang bertempat tinggal/berdomisili pada suatu wilayah atau daerah dan dihitung dalam satuan jiwa.

d. Produk Domestik Regional Bruto (PDRB)

Jumlah nilai tambah barang dan jasa yang dihasilkan dari seluruh kegiatan pekonomian diseluruh daerah dalam tahun tertentu atau periode tertentu dan biasanya satu tahun.

\section{e. Pajak daerah}

Iuran wajib yang dilakukan oleh orang pribadi atau badan kepada daerah tanpa imbalan langsung yang seimbang, yang dapat dipaksakan berdasarkan peraturan perundang-undangan untuk membiayai penyelenggaraan pemerintah daerah dan pembangunan daerah.

f. Retribusi daerah

Retribusi Daerah adalah pungutan daerah sebagai pembayaran atas jasa atau pemberian izin tertentu yang khusus disediakan dan atau diberikan oleh pemerintah daerah untuk kepentingan orang pribadi atau badan.

g. Hasil Pengelolaan kekayaan Daerah yang dipisahkan

Hasil Pengelolaan Kekayaan Daerah yang dipisahkan merupakan penerimaan daerah yang berasal dari hasil perusahaan milik daerah dan pengelolaan kekayaan daerah yang dipisahkan. Penerimaan ini antara lain dari BPD, perusahaan daerah, dividen BPRBKK dan penyertaan modal daerah kepada pihak ketiga.

h. Lain-lain pendapatan asli daerah yang sah

Lain-lain Pendapatan Asli Daerah merupakan penerimaan daerah yang berasal dari lain-lain milik pemerintah daerah. Penerimaan ini berasal dari hasil penjualan barang milik daerah, dan penerimaan jasa giro.

\subsection{Populasi Dan Sampel}

Populasi adalah keseluruhan aspek yang menjadi objek yang akan diteliti, sedangkan sampel adalah sebagian dari jumlah dan karakteristik yang dimiliki oleh populasi tersebut. dalam penelitian ini data yang digunakan data time series atau data runtut waktu, maka dari itu populasi yang digunakan sekaligus menjadi sampel yaitu jumlah penduduk, PDRB , pajak daerah, retribusi daerah, hasil pengelolaaan kekayaan daerah yang dipisahkan, dan lain-lain pendapatan asli daerah yang sah dikabupaten Majene dari tahun 2006 - 2015.

\subsection{Teknik Pengumpulan Data}

Tehnik pengumpulan data adalah memperoleh data yang dilakukan merekam kejadian,menghitung, mengukurnya, dan mencatatnya. Dalam penelitian ini beberapa teknik dalam pengumpulan data yaitu :

\subsubsection{Observasi}

Peneliti mengadakan pengamatan langsung dilapangan terhadap objek yang diteliti. Hal ini dimaksudkan untuk lebih menjamin objektivitas data dilapangan. Kemungkinan untuk dicatat secara langsung sehingga dapat dikontrol validitasnya dan reabilitasnya

\subsubsection{Dokumentasi}

Pengumpulan data dengan dokumentasi ini dimaksud untuk memperoleh data sekunder keadaan pendapatan asli daerah kabupaten Majene. Data mengenai variabelvariabel dalam penelitian ini dapat diperoleh dari dokumentasi (pencatatan buku) karena pada dasarnya penelitian ini menggunakan data sekunder berupa data time series. 


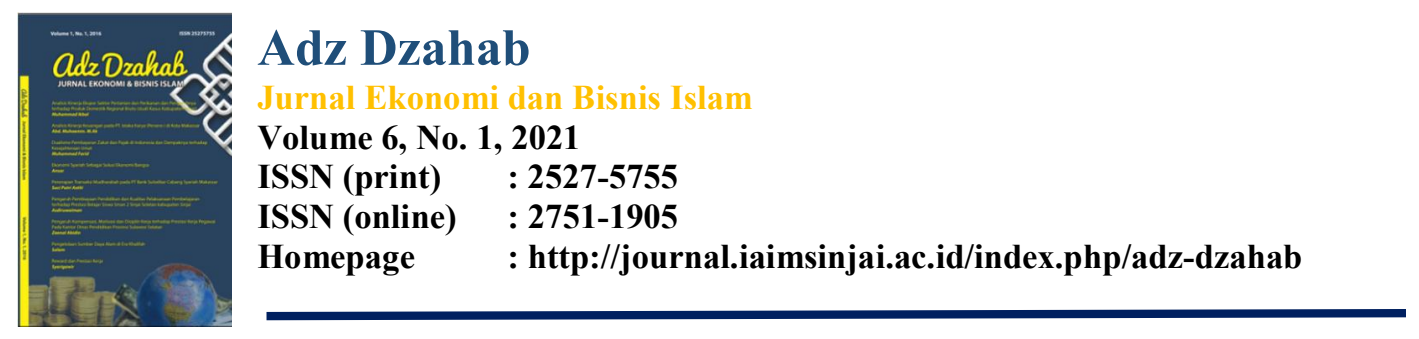

2.5.3. Teknik Analisis Data

Adapun teknik analisis data yang digunakan dalam penelitian ini adalah statistik inferensial yaitu analisis regresi berganda dengan menggunakn Statistical Product and Service Solution 20 (SPSS 20) seperti halnya yang dirumuskan oleh Gujaratih (2006) sebagai berikut:

\subsubsection{Analisis Deskriptif}

Analisis deskriptif dilakukan untuk memberi gambaran yang jelas mengenai sekumpulan data yang diperoleh nantinya. Maka dari itu dalam penyajian deskriptif bertujuan untuk dapat memberikan gambaran yang jelas mengenai hubungan antar variabel yang ada.

\subsubsection{Metode Regresi Berganda}

Untuk mengetahui pengaruh variable bebas yaitu Jumlah Penduduk, PDRB, Pajak Daerah, Retribusi, Hasil Kekayaan yang di Pisahkan dan lai-lain pendapatan yang sah dan variable terikat yaitu Pendapatan Asli Daerah (PAD) digunakan analisis linear berganda sebagai berikut :

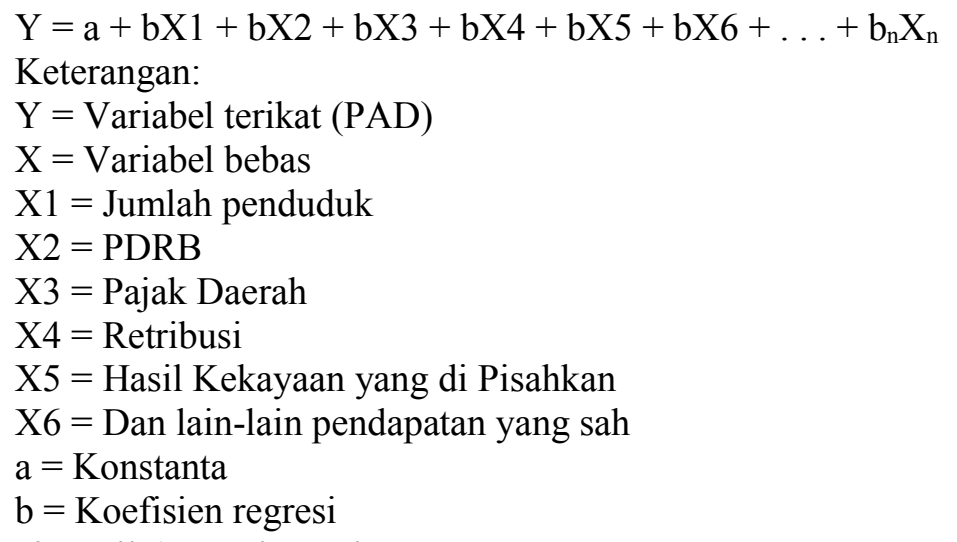

\subsubsection{Uji Asumsi Klasik}

Dalam menggunakan alat analisis regresi, perlu dilakukan pengujian asumsi klasik, agar hasil analisis regresi ini menunjunkkan hubungan yang valid.

\section{a. Uji Normalitas}

Uji normalitas bertujuan untuk menguji apakah dalam model regresi, baik variabel dependen maupun variabel independen, keduanya mempunyai distribusi normal atau tidak. Model model regresi yang baik adalah, model regresi yang mempunyai distribusi normal atau mendekati normal (Imam Ghozali, 2001). Uji normalitas menguji apakah model regresi variabel independen dan variabel dependen, keduanya terdistribusikan secara normal atau tidak. Uji ini adalah untuk menguji normal atau tidaknya suatu distribusi data. Pedoman pengambilan keputusan:

a) Nilai Sig. Atau signifikansi atau Nilai Probabilitas $<0,05$ maka, distribusi adalah normal.

b) Nilai Sig. Atau Sifnifikansi atau Nilai Probabilitas $>0,05$ maka, distribusi adalah normal.

\section{b. Uji Multikolinearitas}

Penyimpanan asumsi model klasik yang pertama adalah adanya multikolinearitas dalam model regresi yang dihasilkan. Artinya, antarvariabel independen yang terdapat dalam model memiliki hubungan yang sempurna atau mendekati sempurna (Koefisien korelasinya timggi atau bahkan 1). Untuk mengetahui apakah terjadi multikolinearitas didalam model regresi adalah sebagai berikut: 


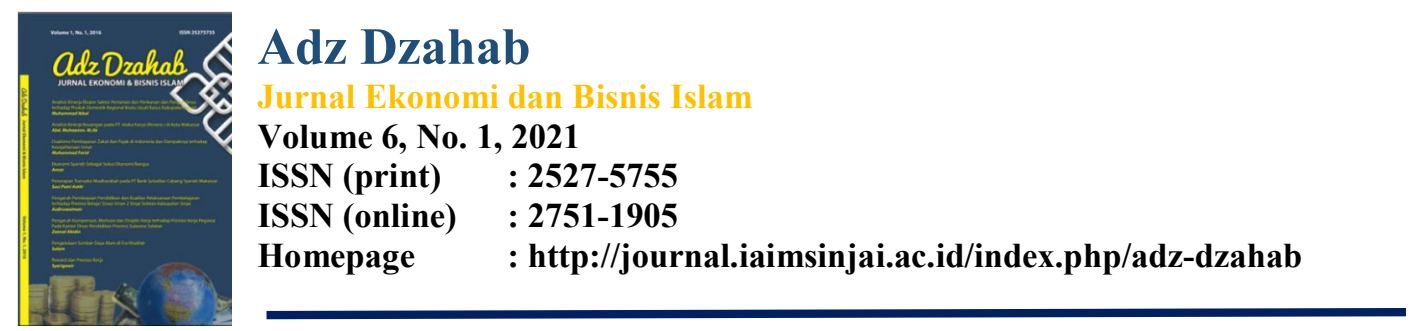

a) Menurut Gujarati , mengatakan bahwa tanda paling jelas adanya multikolinearitas adalah ketika $R^{2}$ sangat tinggi tetapi tidak satupun koefisien regresi signifikan secara statistik atas dasar uji t (secara individula)

b) Multikolinearitas dapat dilihat dari nilai tolerance dan VIF (variance Inflation Factor) kedua ukuran ini menunjukkan setiap variabel bebas manakan yang dijelakan oleh variabel lainnya. Tolerance mengukur variabilitas variabel bebas yang terpilih yang tidak dapat dijelakan oleh variabel bebas lainnya. Jadi nilai Tolerance yang rendah sama dengan nilai VIF yang tinggi dan menunjukkan adanya multikolinearitas yang tinggi. Nilai batasan yang umum dipakai adalah nilai Tolerance 0,10 atau sama dengan nilai VIF lebih besar dari 10. Rumus nilai VIF adalah $1 /$ Tolerance.

c) Menganalisis matrik korelasi valiabel-variabel bebas. Jika antar variabel bebas ada korelasi yang cukup tinggi (umumnya diatas 0,90 ), maka hal ini merupakan adanya indikasi adanya multikolinearitas.

\section{c. Uji Autokorelasi}

Uji autokorelasi digunakan untuk menguji apakah dalam suatu model regresi ada korelasi antar kesalahan pengganggu pada periode $t$ dengan kesalahan pada periode $t-1$. Autokorelasi terjadi karena observasi yang berurutan sepanjang waktu berkaitan satu sam lain. Menurut Gujarati (1995: 157), autokorelasi dapat didefinisikan sebagai korelasi anggota serangkain observasi yang yang diurutkan seperti data menurut waktu (deret waktu/time series) atau dalam cross section.

Pengujian yang digunakan untuk mengetahui adanya autokorelasi adalah uji statistik Durbin Watson diantaranya:

a) Terjadi autokorelasi positif $(0<\mathrm{d}<\mathrm{dl})$

b) Daerah keragu-raguan $(\mathrm{dl}<\mathrm{d}<\mathrm{du})$

c) Tidak terjadi autokorelasi $(\mathrm{du}<\mathrm{d}<4-\mathrm{du})$

d) Daerah keragu-raguan $(4-\mathrm{du}<\mathrm{d}<4-\mathrm{dl})$

e) Terjadi autokorelasi negatof $(4-\mathrm{dl}<\mathrm{d} 4)$

\section{d. Uji Heteroskedastisitas}

Uji Heteroskedastisitas bertujuan untuk menguji, apakah model regresi terjadi ketidak samaan variabel dari residula satu pengamatan yang lain, salah satu cara untuk mendeteksi ada atau tidaknya heteroskedastisitas itu dengan melihat grafik plot antar nilai ptrediksi dengan residualnya (Gujarati, 1995). Adapun dasar untuk menganalisinya adalah:

a) Jika ada pola tertentu (bergelombang, melebar, kemudian menyempit) maka, mengindikasikan bahwa telah terjadi heteroskedastisitas.

b) Jika ada polah tertentu serta titik menyebar diatas dan dibawah angka nol pada sumbu Y maka, tidak terjadi heteroskedastisitas.

\section{e. Uji F}

Hal ini dilakukan dengan cara pengujian terhadap variabel-variabel independent secara bersama-sama yang dilakukan untuk melihat pengaruh variabel independent secara simultan terhadap variabel dependent. Dalam penelitian ini melakukan uji $\mathrm{F}$ dengan mengguanakn probabilitas, perhitungannya adalah sebagai berikut:

$$
\text { Fhitung }=\frac{K-1}{\left(1-R^{2}\right)(n-K)}
$$

Keterangan:

$\mathrm{R}^{2} \quad:$ Koefisien determinasi

$\mathrm{n} \quad$ : Jumlah sampel

$\mathrm{K} \quad$ : Banyaknya parameter /koefisien regresi 


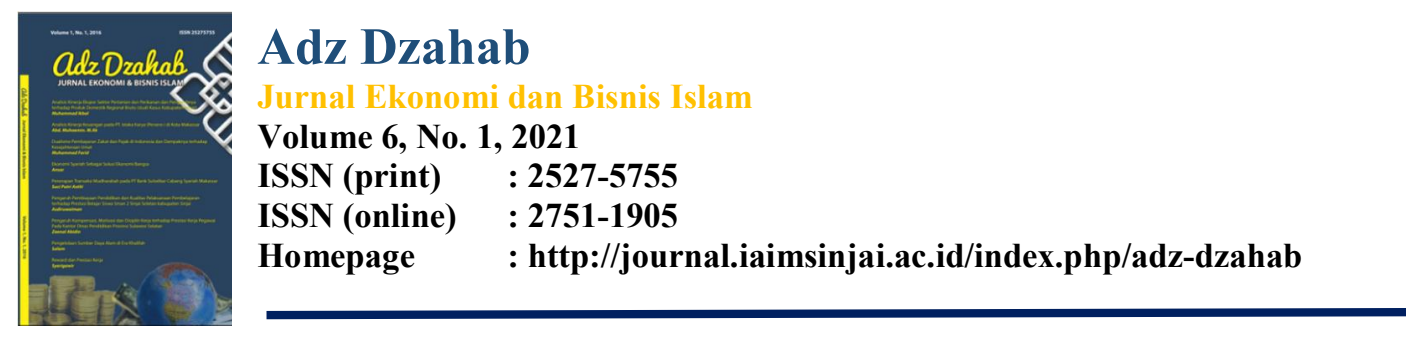

Taraf signifikan yang digunakan adalah 0,05. Dalam penelitian ini Satistical product and service solution (SPSS) sehingga uji t nantinya dapat dilihat pada tabel anova.

Adapaun Hipotesis yang digunakan nantinya, sebagai berikut:

a) H0 : $\beta 1=\beta 2=\beta 3=\beta 4=0$, maka variabel independen secara bersama-sama tidak mempengaruhi variabel dependen.

b) H1 : $\beta 1 \neq \beta 2 \neq \beta 3 \neq \beta 4 \neq 0$, maka variabel independen secara bersama-sama mempengaruhi variabel dependen.

Dengan demikian dapat digambarkan sebagai berikut:

a) Jika f hitung $\geq \mathrm{f}$ tabel Berarti:

H0 ditolak dan H1 diterima yang berati bahwa variabel jumlah penduduk (X1) Inflasi (X2) PDRB (X3) berpengaruh secara simultan terhadap pendapatan asli daerah $(\mathrm{Y})$.

b) Jika fhitung $\leq$ ftabel Berarti:

H0 diterima dan $\mathrm{H} 1$ ditolak yang berarti bahwa variabel jumlah penduduk (X1) Inflasi (X2) PDRB (X3) tidak berpengaruh secara simultan terhadap pendapatan asli daerah (Y).

f. Uji t

Uji t dilakukan dengan pengujian variabel-variebel indpenden secara parsial (individu), digunakan untuk mengetahui sifnifikansi dan pengaruh variabel independen secara individu terhadap variasi veriabel dependen.

Uji t hitung dapat dilakukan dengan rumus sebagai berikut:

$$
t=\frac{b t}{s b t}
$$

Dimana $b$ merupakan koefisisen regresi masing-masing variabel bebas dan $\mathrm{sb}$ adalah simpangan baku masing-masing variabel bebas. Adapun taraf signifikan yang digunakan adalah 0,05. Dalam penelitian ini digunakan metode statistical product and service solution (SPSS) sehingga untuk hasil uji t dapat dilihat pada tabel coefficient.

Hipotesis dalam uji $\mathrm{t}$ adalah sebagai berikut:

1) H0 : $\beta 1=0$, maka variabel independen secara parsial tidak mempengaruhi variabel dependen.

2) H1 : $\beta 1 \neq 0$, maka variabel independent secara parsial mempengaruhi veriabel dependen.

Dengan kriteria sebagai berikut:

a) Jika thitung $\geq$ ttabel Berarti:

H0 ditolak H1 diterima yang bebarti bahwa jumlah penduduk (X1), PDRB (X2)

inflasi (X3) berpengaruh secara parsial terhadap pendapatan asli daerah (Y).

b) Jika thitung $\leq$ ttabel Berarti:

H0 ditolak H1 ditolak yang bebarti bahwa variabel jumlah penduduk (X) PDRB (X2)

inflasi (X3) tidak berpengaruh secara parsial terhadap pendapatan asli daerah (Y).

\subsection{Analisis Koefisien Korelasi}

Metode koefisien korelasi digunakan untuk menentukan hubungan variabel bebas, terhadap veriabel terikat dengan program SPSS pada tabel model Summary. Nilai $\mathrm{R}^{2}$ menunjukkan besarnya variabel-variabel independen dalam mempengaruhi variabel dependen. Nilai $\mathrm{R}^{2}$ berkisar antara 0 dan $1\left(0 \leq \mathrm{R}^{2} \leq 1\right)$. Semakin besar nilai $\mathrm{R}^{2}$, maka semakin besar variabel-variabel dependen yang dijelaskan oleh variasi variabel-variabel independen. Sebaliknya kecil nilai $\mathrm{R}^{2}$, maka semakin kecil variasi varabel dependen yang dapat dijelaskan oleh variasi variabel independen. 


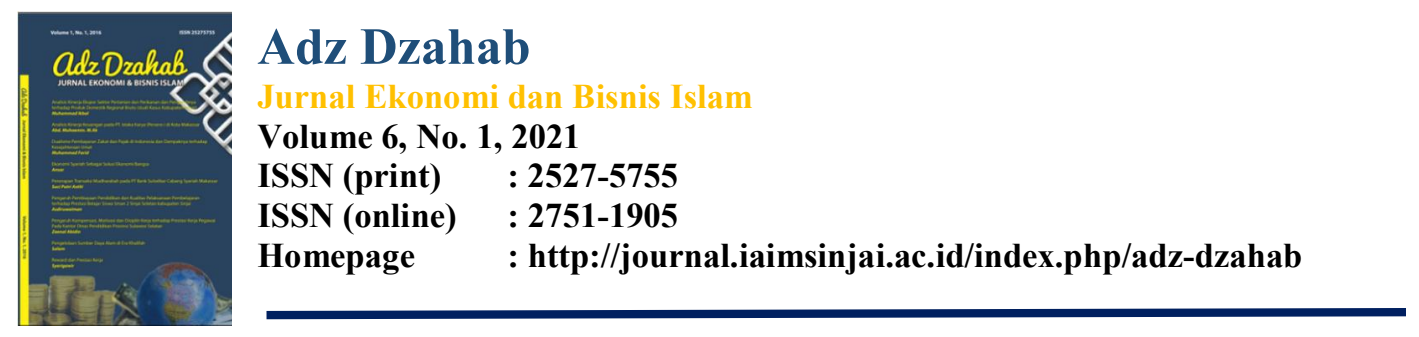

\section{Hasil Penelitian Dan Pembahasan}

\subsection{Gambaran Umum Kabupaten Majene \\ 3.1.1. Kondisi Geografis}

Kabupaten Majene merupakan salah satu dari 6 kabupaten dalam wilayah Propinsi Sulawesi Barat yang terletak di pesisir Pantai Barat Propinsi Sulawesi Barat memanjang dari Selatan ke Utara. Letak geografis Kabupaten Majene berada pada antara 20 38' 45" 30 38' 15" Lintang Selatan dan antara 1180 45'00" - 1190 4' 45" Bujur Timur, dengan jarak ke ibukota Propinsi Sulawesi Barat (Kota Mamuju) kurang lebih 146 km. Luas wilayah Kabupaten Majene adalah 947,84 km2 atau 5,6\% dari luas Propinsi Sulawesi Barat. Adapun batas-batas Kabupaten Majene adalah sebagai berikut:

- Sebelah Utara : Kabupaten Mamuju

- Sebelah Timur : Kabupaten Polewali Mandar

- Sebelah Selatan : Teluk Mandar

- Sebelah Barat : Selat Makassar

Kondisi iklim wilayah Kabupaten Majene dan sekitarnya secara umum ditandai dengan hari hujan dan curah hujan yang relatif tinggi. Hal ini sangat dipengaruhi oleh angin musim disebabkan wilayahnya berbatasan dengan laut lepas (Selat Makassar dan Teluk Mandar). Kondisi iklim di Kabupaten Majene memiliki rata-rata temperatur berkisar 27,850 C, dengan suhu minimum 27,10 C dan suhu maksimum 28,600 C.

Dari 8 kecamatan yang masuk dalam wilayah adminsitrasi Kabupaten Majene, Kecamatan Banggae dan Kecamatan Banggae Timur merupakan kecamatan yang terletak di Ibukota Kabupaten Majene, dengan kondisi wilayah yang relatif datar. Sedangkan enam kecamatan lainnya yaitu Pamboang, Sendana, Tammerodo, Tubo, Malunda \& Ulumanda didominasi wilayah berbukit dan pegunungan. Persentase luas wilayah Kabupaten Majene dengan rata-rata ketinggian lokasi yang berada pada ketinggian 100 - 500 mdpl adalah $38,7 \%$.

Berdasarkan klasifikasi bentang lahan, Kecamatan Banggae dan Banggae Timur merupakan wilayah yang relatif lebih datar, sedangkan wilayah kecamatan lainnya lebih dominan berupa wilayah berbukit dan pegunungan. Berdasarkan klasifikasi wilayah menurut kelas ketinggian tempat dari permukaan laut, wilayah Kabupaten Majene yang berada pada kelas ketinggian $100-500$ mdpl mencapai 38,7\% dari luas wilayah kabupaten dan yang berada pada ketinggian $500-1000$ mdpl mencapai 35,98\%.

\subsubsection{Pendapatan Asli daerah}

Pendapatan asli daerah (PAD) merupakan salah satu sumber dana pembiayaan pembangunan daerah maka dari itu semakin besar kontribusi PAD maka semakin besar pula dana pembiayaan daerah, untuk itu pemerintah daerah diharuskan menggali dan meningkatkan pendapatan daerah terutama sumber pendapatan asli daerah.. Sumbersumber PAD sesuai dengan peraturan pemerintah nomor 91 tahun 2010 tentang jenis pajak daerah yang dipungut berdasarkan penetapan kepala daerah atau yang dibayar sendiri oleh wajib pajak, pemerintah kabupaten Majene melalui Dinas pendapatan Daerah Kabupaten Majene :

a. Pajak daerah yang meliputi :

1) Pajak hotel

2) Pajak restoran

3) Pajak hiburan

4) Pajak reklame

5) Pajak penerangan jalan

6) Pajak pengambilan/penggalian galian Gol. C

7) Bagi hasil dari bea perolehan hak atas tanah dan bangunan 


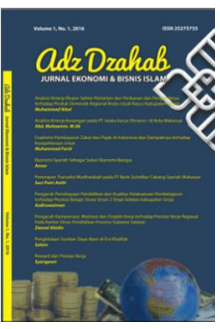

b. Retribusi daerah yang meliputi :

1) Retribusi jasa umum

2) Retribusi jasa usaha

3) Retribusi pemakaian kekayaan daerah

4) Retribusi perizinan tertentu

c. Hasil pengelolaan kekayaan daerah yang dipisahkan yang meliputi :

1) Bagian laba atas penyertaan modal pada perusahaan/BUMD

d. Lain-lain pendapatan asli daerah yang sah yang meliputi :

1) Hasil penjualan asset daerah yang dipisahkan

2) Penerimaan jasa giro

3) Pendapatan dari pengembalian

4) Pendapatan dari penyelenggaraan pendidikan dan pelatihan

\subsubsection{Pajak daerah}

Pajak daerah adalah pajak-pajak yang dipungut oleh daerah-daerah seperti propinsi, kabupaten maupun kotamadya berdasarkan peraturan daerah masing-masing dan hasil pemungutannya digunakan untuk pembiayaan rumah tangganya masing-masing (Simanjuntak, 2003:32). Wewenang mengenakan pajak atas penduduk untuk membiayai layanan masyarakat merupakan unsur sangat penting dalam pemerintahan daerah.

1. Jenis-jenis pajak daerah

Berdasarkan Undang -Undang No.28 Tahun 2009 jenis-jenis pajak daerah adalah :

a. Pajak Hotel

b. Pajak Restoran

c. Pajak Hiburan

d. Pajak Reklame

e. Pajak Penerangan Jalan

f. Pajak Mineral Bukan Logam dan Batuan

g. Pajak Parkir

h. Pajak Air Tanah

i. Pajak Sarang Burung Walet

j. Pajak Bumi dan Bangunan Perdesaan dan Perkotaan

k. Bea Perolehan Hak atas Tanah dan Bangunan

Menurut Peraturan Pemerintah 55 Tahun 2016 tentang pajak daerah ketentuan umum dan pemungutan pajak daerah dalam pasal 4 bahwa pajak daerah ditetapkan dengan peraturan daerah yang berarti daerah memiliki kewenangan mengatur tentang pajak daerahnya. Penerimaan pajak terbanyak di Kabupaten Majene banyak bersumber dari pajak penerangan jalan, adapun jenis-jenis pajak yang ditetapkan pemerintah daerah antara lain
a. Pajak Hotel
b. Pajak rumah makan
c. Pajak hiburan
d. Pajak reklame
e. Pajak penerangan jalan
f. PBB-P2
g. BPHTB
h. Pajak galian Gol. C

Berdasarkan analisis pengaruh pertumbuhan penduduk, produk domestik regional bruto, pajak daerah, retribusi daerah, hasil pengelolaan kekayaan daerah yang dipisahkan dan lain-lain PAD yang sah terhadap Pendapatan Asli Daerah maka dapat diambil kesimpulan sebagai berikut : 


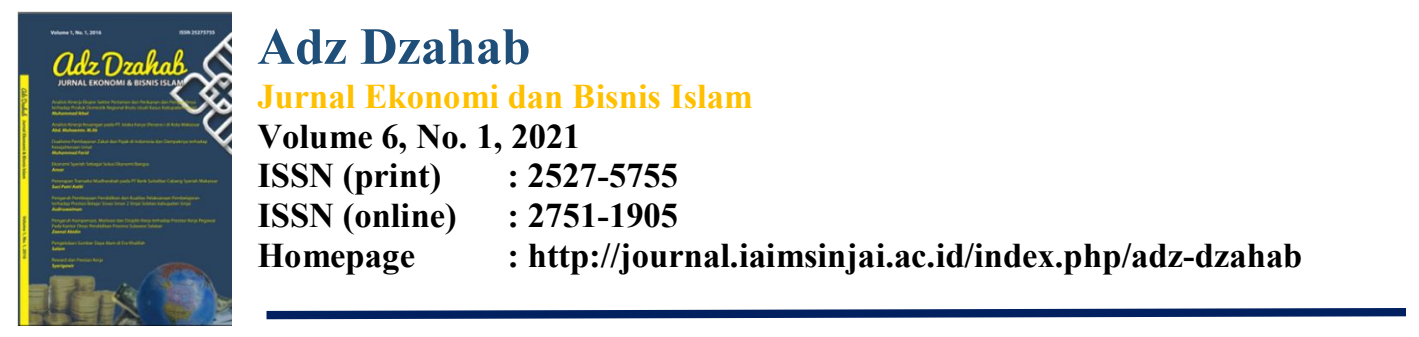

a. Secara parsial pertumbuhan penduduk berpengaruh tetapi tidak signifikan terhadap pendapatan asli daerah kabupaten Majene, produk domestik regional bruto berpengaruh dan signifikan terhadap pendapatan asli daerah kabupaten Majene, pajak daerah berpengaruh dan signifikan terhadap pendapatan asli daerah kabupaten majene, retribusi daerah berpengaruh dan signifikan terhadap pendapatan asli daerah kabupaten majene, hasil pengelaloaan kekayaan daerah yang dipisahkan berpengaruh tetapi tidak signifikan terhadap pendapatan asli daerah kabupaten Majene, lain-lain pendapatan asli daerah yang sah berpengaruh dan signifikan terhadap pendapatan asli daerah kabupaten Majene.

b. Secara simultan jumlah penduduk, produk domestik regional bruto, pajak daerah, retribusi daerah, hasil pengelolaan kekayaan daerah yang dipisahkan dan lain-lain pendapatan asli daerah berpengaruh dan signifikan terhadap pendapatan asli daerah dikabupaten Majene.

\section{Daftar Pustaka}

Atmaja Eka Arief, Hendarto Mulyono R. Tanpa tahun.Tesis. Analisis faktor-faktor yang mempengaruhi pendapatan asli daerah (PAD) dikota Semarang.

Asmaruf F Makdalena, Rumate A Vikie, Kawung M.V Kawung. 2015. Pengaruh dan jumlah penduduk terhadap pendapatan asli daerah dikabupaten Sorong. Jurnal Berkala Ilmiah Efisiensi. Volume 15 No. 05 Tahun 2015.

Aswar Hajar Siti. 2015. Analisis faktor yang memengaruhi pendapatan asli daerah (PAD) dikota Makassar. Tesis. Tidak Dipublikasikan. Program Pascasarjana UNM Makassar

Atep Adya Barata. Tanpa tahun. Pendapatan Asli Daerah. “Terjemahan Barata”Jakarta. 2004

Aziz. 1997. Pendapatan Asli Daerah. Jakarta. Erlangga

Badan Pusat Statistik. 2016. Majene Dalam angka. BPS

Beta Aztena. 2015. Analisis Pengaruh Penerimaan Pajak Daerah Dan

Retribusi Daerah Terhadap Pendapatan Asli Daerah Kabupaten/Kota di Jawa Tengah. Jurnal Riset Managemen . Volume 2 Tahun 2015

Deliarnov. 2010. Perkembangan Pemikiran Ekonomi. Jakarta. PT Grafindo Persada

Tadoro, (1997). "Pertumbuhan Ekonomi". Jakarta

Gujarati N. Damodar, Dawn C. Porter. 2015. Dasar-dasar ekonometrika. Salemba Empat. Jakarta

Kuncoro Mudrajat. 2015. Indikator Ekonomi. Yogyakarta. UPP STIM YKPN

Mankiw, N.G. (2006). Makro Ekonomi. Jakarta: Erlangga

Mandar News (online). Resmi disahkan rincian

APBD2017 http://mandarnews.com/2016/12/29/resmi-disahkan-berikut-rincianapbd-2017/ diakses tanggal 1 maret 2017

Murib pidelis, Rotinsulu C. Debby, Tolosang D Krest. 2016. Pengaruh pendapatan perkapita, jumlah penduduk, dan jumlah perusahaan terhadap pendapatan. asli dearah dikabupaten nabire papua 2004-201.Jurnal Berkala Ilmiah Efisiensi.Volume 16 No. 01 Tahun 2016

Mardiasmo. 2002. Perpajakan Edisi Revisi. Yogyakarta: Andi Offset.

Mayza Miragustia. Jurnal. Analisis Faktor-Faktor Yang Mempengaruhi

Pendapatan Asli Daerah Provinsi Aceh. ISSN 2302-0172 pp. 9- 16. 


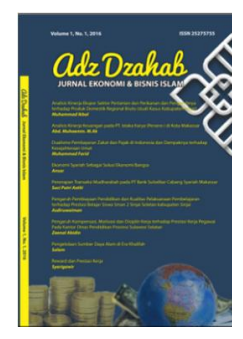

M. Zahari MS. 2016. Pengaruh Pajak dan Retribusi Daerah Terhadap

Pendapatan Asli Daerah Kabupaten Sarolangun. Eksis Vol. 7 No. 2

Putong Iskandar. 2013. Economics Pengantar Mikro dan Makro. Mitra Wacana Media. Jakarta

Md. Krisna Arta Anggar, Ni Gst Putu Wirawati. Tanpa tahun. Jurnal. Analisis Pengaruh Penerimaan Pajak dan Retribusi Terhadap Penerimaan PAD Sekabupaten/Provinsi Bali. E-Jurnal Akuntansi Universitas Udayana 5.3 (2013):574- 585. ISSN: 2302-8556

Purwaningsih, E. 2011. Analisis Faktor yang Mempengaruhi Pendapatan Asli Daerah di Kabupaten Sragen Tahun 1992-2008. Tesis. Diterbitkan. Surakarta: Program Pascasarjana Universitas Sebelas Maret).

Rani El Sarawati Fitria Hening. Tanpa tahun. Analisis faktor -faktor yang mempengaruhi pendapatan asli daerah (PAD) (studi kasus dikabupaten/kota Eks-Karesidenan Pekalongan periode 2005-2014.

Susanto Iwan. 2014. Analisis Pengaruh PDRB, Penduduk, dan Inflasi terhadap Pendapatan Asli Daerah (PAD) (Studi Kasus Malang 1998-2012).

Sari Nani, Rahmatia, Amar Yunus Amar. Tanpa Tahun. Faktor-faktor yang mempengaruhi pendapatan asli daerah dikabupaten Morowali tahun $2003-2012$.

Sandi. 2014. Analisis Faktor Yang mempengaruhi Pendapatan Asli Daerah dikabupaten Bone. Program pascasarjana UNM. Makassar. Tesis. Tidak diterbitkan. Makassar : Program Pascasarjana UNM Makassar Sukirno, (2004). Pengantar Teori Makro Ekonomi. Jakarta Press, Jakarta Undang-unndang No 32. Tahun 2004. Undang-undang otonomi daerah. Jakarta. $\quad$ Fokus media.

Widjaja HAW. 2005. Penyelenggaraan otonomi diindonesia. PT Raja Grafindo Persada. Jakarta

Undang-Undang No 17 tahun 2003 Tentang Keuangan . Jakarta. Fokus media. 